\title{
Evaluation of the Influence of Upset Stage on Joint Properties of Friction Welded Dissimilar Aluminum-Copper Cast Alloys
}

\author{
Zafer Barlas* - Murat Çolak \\ Sakarya University, Technology Faculty, Turkey
}

Friction welding was applied to dissimilar aluminum cast bars alloyed with 2 and $8 \%$ copper and the effects of upset time on joint properties were evaluated in this study. The welding process was carried out by a vertical milling machine. Tensile test results show that the ultimate tensile strength increased with an increase in upset time and it reached $88 \%$ for Al-2\%Cu and $74 \%$ for Al-8\% Cu base metals. The heat affected zone, thermo-mechanical affected zone, and weld metal were detected in this joint by optical examination, in addition to the base metals. $A$ peak temperature of $436{ }^{\circ} \mathrm{C}$ was measured in the weld zone. Hardness values also varied according to microstructural changes. The highest hardness values were detected in the weld metal and its average hardness was 217 Brinell.

Keywords: friction welding, Al-Cu cast alloy, upset stage, tensile strength, microstructure, weld temperature

\section{INTRODUCTION}

Aluminum-copper (Al-Cu) cast alloys (2XX.X series) are widely used in various industrial applications due to their high strength and hardness properties in the ascast state in spite of their low corrosion resistance, low fluidity and ductility. However, joining of Al-Cu cast alloys by conventional welding processes is difficult or not recommended because of its susceptibility to stress-corrosion cracking and hot cracks [1] to [3]. A literature survey shows that there is also a lack of research on the weldability of $\mathrm{Al}-\mathrm{Cu}$ cast alloys by solid-state welding techniques.

Friction welding (FW) is one kind of solid-state welding process where the heat required for joining is produced by mechanical friction at the interface of the work-pieces. The work-pieces to be joined are first prepared so as to have smooth, square-cut surfaces. While one of the work-pieces remains stationary, the other is rotated against the first piece at high speed under applied pressure. As soon as the interface temperature has reached an optimum value for plastic deformation, the rotation is stopped and the forging pressure is further increased to complete the weld [4] to [6]. Some process parameters have significant effects on producing sound welds. These are: (i) rotational speed, (ii) friction pressure, (iii) friction time, (iv) forging (upset) pressure, and (v) forging time. The other parameters such as feed rate, upset delay time, and brake delay time should be considered for a good weld [7] to [9]. In addition to similar metals, FW is also suitable for welding dissimilar metals with different melting points and physical properties. Therefore, many papers have been reported about the effects of these FW parameters on the weld quality in joining of similar and dissimilar metal groups. According to a study reported by Rafi et al. [10], relatively high friction pressure, high rotation speed and lower forging pressure should be used to create high joint strength in AA7075-T6 aluminum alloy. Sathiya et al. [11] looked at the effects of FW parameters in joining ferritic stainless steel pieces. They found out that friction time should be kept as short as possible, while friction and forging pressures should be as high as possible in order to obtain high joint strength. For FW in AZ31 magnesium alloys, higher upset pressure was caused the grain refinement and increasing hardness near the weld interface [12]. Kurt et al. [5] focused on friction welded dissimilar AISI 1010 mild steel to ASTM B22 copper bronze joints properties at various friction pressures and upset pressures, as well as upset time, under a constant rotation speed and friction time conditions. The upset and friction pressures and times are key parameters according to the authors. They observed that the tensile strengths of the joints increased up to a certain value with an increase in friction pressure and that the hardness generally also increased with increasing friction and upset pressures, but that hardness values decreased with increasing upset time. A similar study about dissimilar $6063 \mathrm{Al}$ alloy/ austenitic stainless steel was carried out by Sammaiah et al. [13]. They recommended low friction pressure and high upset pressure in order to obtain high joint strength. Manideep and Balachandar [14] examined the microstructure and hardness distribution of FW parameters for joining of dissimilar stainless steels. They explained that high upset pressure resulted in a fine grain structure in HAZ and high hardness, while higher friction pressure leads to grain coarsening for FW of AISI 321 to AISI 430 stainless steel. Another study about friction welding of 6061-T6 aluminum 
and AISI 1018 steel by Taban et al. [15] revealed that higher forge pressure led to higher tensile strength. Sahin [16] studied the effect of friction stage on dissimilar $\mathrm{Al} / \mathrm{Cu}$ joint strength and observed that if friction time and pressure are increased, tensile strength increases up to a certain peak point, then decreases with higher friction time and pressure. Similar results were presented by Ratkovic et al. [17] in a study on FW of dissimilar $\mathrm{Al}$ and $\mathrm{Cu}$. They found that the tensile strength of the joints increases up to a certain peak value and then slightly decreases with higher friction time.

The main purpose of the present study is to evaluate the effects of upset stage including pressure and time in friction welded $\mathrm{Al}$ cast alloy bars with contents of 2 and $8 \%$ Cu by a vertical milling machine.

\section{MATERIALS AND METHOD}

In the study, dissimilar Al cast alloy bars containing of 2 and $8 \% \mathrm{Cu}$ (in wt.) in dimensions of $20 \mathrm{~mm}$ (diameter) $\times 90 \mathrm{~mm}$ (length) were joined by friction welding. Alloys were poured into a sand mold. Casting alloys were melted in a $\mathrm{SiC}$ crucible using a resistance melting furnace with an $8 \mathrm{~kg}$ capacity. The chemical compositions of the $\mathrm{Al}$ alloys used in the experimental studies are shown in Table 1. The friction welding trials were performed using a vertical milling machine. Al alloy bar with $8 \% \mathrm{Cu}(\mathrm{Al}-8 \% \mathrm{Cu})$ was rotated (rotation side, $\mathrm{RS}$ ) while the $\mathrm{Al}$ alloy bar with $2 \% \mathrm{Cu}(\mathrm{Al}-2 \% \mathrm{Cu})$ was fixed (stationary side, $\mathrm{SS})$ via a clamp on the worktable equipped with load-cells. Table 2 shows the welding parameters used. As shown in Table 2, the effects of upset stage (pressure and time) have been studied. Upset forces of 7.5 and 10 $\mathrm{kN}$ and upset times of 20,50, and $80 \mathrm{~s}$ were employed under a constant friction force of $2.5 \mathrm{kN}$, friction time of $60 \mathrm{~s}$ and friction speed of $1500 \mathrm{rpm}$. These applied forces were divided into the cross-sectional area of the aluminum bar thus these values were presented as the friction pressure and upset pressure, respectively. Increasing temperature during the welding processes was measured $3 \mathrm{~mm}$ below the abutted surface and at a depth of $2.5 \mathrm{~mm}$ from the outer surface of the Al-2\% Cu bar using a K-type thermocouple. Tensile testing was carried out on a Shimadzu tester (model AG-IC) with a $50 \mathrm{kN}$ capacity at a cross-head speed of $2 \mathrm{~mm} \times \mathrm{min}^{-1}$ in order to evaluate the friction weld trials and base alloys strength. The geometry of the tensile test specimens is shown in Fig. 1 [18]. Brinell and Vickers hardness test methods were carried out in order to observe the hardness distribution and features of the joint having the highest ultimate tensile strength
(UTS) value. The Brinell hardness test was performed using a $2.5 \mathrm{~mm}$ diameter ball and a $612.9 \mathrm{~N}$ indentation force on across the cross-section of the weld zone and near the weld interface. A load of $200 \mathrm{~g}$ and dwell time of $10 \mathrm{~s}$ were employed in the Vickers test. The crosssection perpendicular to the weld interface of the weld zones was polished and then etched with Keller's reagent (1.5 ml hydrochloric acid, $2.5 \mathrm{ml}$ nitric acid, $1 \mathrm{ml}$ hydrofluoric acid and $95 \mathrm{ml}$ water). A Nikon Eclipse L150A optical microscope with computer assisted image analysis (Clemex Vision Lite) was used for microstructural examination. A scanning electron microscope (SEM) equipped with an energy dispersive X-ray spectroscopy (EDS) apparatus and $\mathrm{X}$-ray diffraction (XRD) analysis were also used on the weld zone and tensile fracture surface of the joint having the highest UTS value.

Table 1. Chemical composition of Al alloys (wt.\%)

\begin{tabular}{lcccccc}
\hline Alloy & $\mathrm{Si}$ & $\mathrm{Fe}$ & $\mathrm{Cu}$ & $\mathrm{Mn}$ & $\mathrm{Mg}$ & $\mathrm{Al}$ \\
\hline $\mathrm{Al}-2 \% \mathrm{Cu}$ & 0.11 & 0.21 & 2.04 & 0.023 & 0.012 & bal. \\
\hline $\mathrm{Al}-8 \% \mathrm{Cu}$ & 0.13 & 0.12 & 8.11 & 0.021 & 0.011 & bal. \\
\hline
\end{tabular}

Table 2. Experimental parameters and tensile test results for joining of dissimilar Al alloys by a friction welding process

\begin{tabular}{lccccc}
\hline Sample & $\begin{array}{c}\text { Upset } \\
\text { pressure } \\
{[\mathrm{MPa}]}\end{array}$ & $\begin{array}{c}\text { Upset } \\
\text { time } \\
{[\mathrm{s}]}\end{array}$ & $\begin{array}{c}\text { UTS } \\
{[\mathrm{MPa}]}\end{array}$ & \multicolumn{2}{c}{ Joint efficiency [\%] } \\
\cline { 6 - 7 } & 24 & 20 & 58 & Al-2\%Cu & Al-8\%Cu \\
\hline S1 & 24 & 50 & 83 & 51 & 43 \\
\hline S2 & 24 & 80 & 94 & 58 & 49 \\
\hline S3 & 24 & 20 & 115 & 71 & 60 \\
\hline S4 & 32 & 50 & 121 & 75 & 63 \\
\hline S5 & 32 & 50 & 142 & 88 & 74 \\
\hline S6 & 32 & 80 &
\end{tabular}

Notes: UTS of Al-2\%Cu and Al-8\%Cu base metals are 162 and 193 $\mathrm{MPa}$, respectively. The joint efficiency was calculated by dividing the tensile strength of the welded sample by that of the base metals.

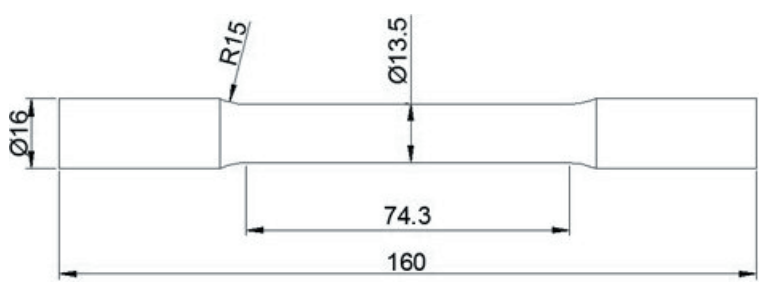

Fig. 1. Geometry of tensile test specimen (units in $\mathrm{mm}$ )

\section{RESULTS AND DISCUSSION}

The overviews and cross-section images of the friction welded S1 having the lowest UTS and S6 having the highest UTS are shown in Fig. 2. Firstly, the weld trials exhibited weld flash due to the upset 
pressure and elevated temperature. But the flashes and the axial shortening occurred relatively more in the $\mathrm{Al}-2 \% \mathrm{Cu}$ alloy, because it is softer and has a higher thermal conductivity than the $\mathrm{Al}-8 \% \mathrm{Cu}$ alloy [5], [10] and [19]. Using a higher upset pressure and time also increased the weld flash amount and caused axial shortening. According to the macro-images for these samples in Figs. 2c and d, FW trials displayed distinguishable weld zone appearances. A linearlike weld interface occurred at the lowest upset time and pressure condition (Fig. 2c), whereas an arc-like weld interface was seen in more plasticized $\mathrm{Al}-2 \% \mathrm{Cu}$ at the highest upset time and pressure (S6) caused by its different mechanical and thermal properties (Fig. 2d). The weld metal area increased with higher upset pressure and time and a symmetrical weld metal occurred in S6 taking into account the axes of the bars. It is clearly seen that inadequate upset time and pressure resulted in a lack of bonding through the abutted surfaces for S1 (Fig. 2c). However, S6 exhibited better bonding despite the local lack of bonding defects indicated by the arrows in Fig. 2 d.
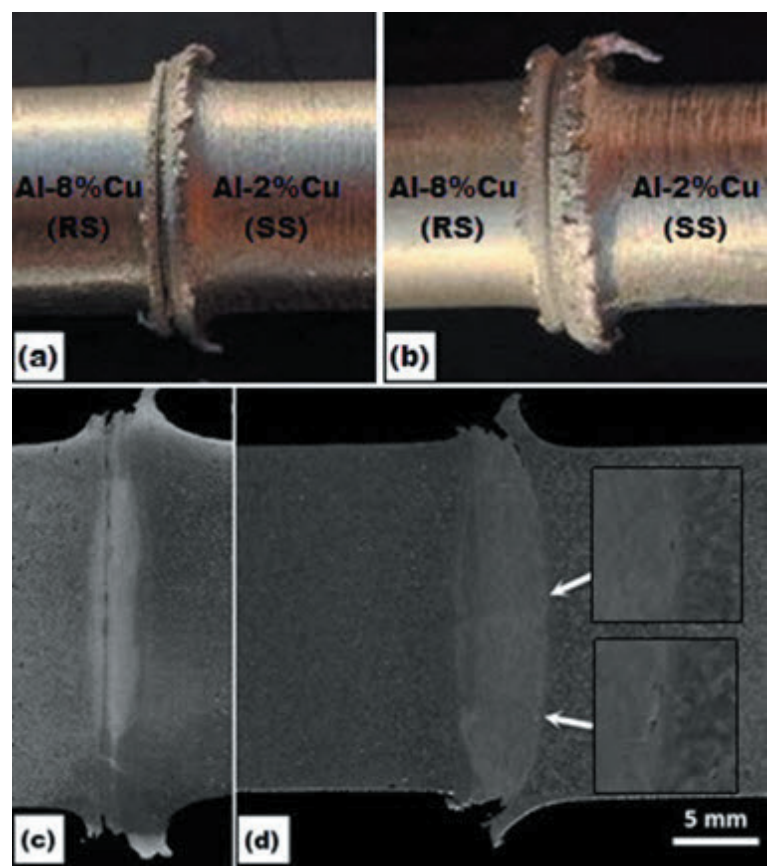

Fig. 2. Appearances and cross-sectional views a) and c) for S1 and b) and d) for 56

The UTS values of dissimilar friction weld trials dependent on upset pressure and time are given in Table 2. As can be clearly seen, the values increased with increasing upset pressure and time. The better bonding was obtained by a higher upset pressure and time. On the other hand, the upset pressure is more influential than the upset time. The highest UTS value (142 MPa) can be achieved at an upset pressure of 32 $\mathrm{MPa}$ and an upset time of $80 \mathrm{~s}$, represented as S6 in Table 2. S6 has a joint efficiency of about 88 and $74 \%$ compared to $\mathrm{Al}-2 \% \mathrm{Cu}$ and $\mathrm{Al}-8 \% \mathrm{Cu}$ base metals, respectively. The fracture for all tensile samples occurred close to the weld interface in the study. Fig. 3 presents SEM image and EDS analysis results, and Fig. 4 shows XRD results obtained from the fractured surface of S6. The SEM micrograph revealed that the brittle mode of fracture primarily took place in the weld zone. This result is akin to that of the as-casted $\mathrm{Al}-8 \% \mathrm{Cu}$ base metal. EDS analysis and $\mathrm{XRD}$ results showed the presence of a brittle $\mathrm{Al}_{2} \mathrm{Cu}$ phase in the fractured surface. Therefore, it can be said that the brittle fracture of intermetallic $\mathrm{Al}_{2} \mathrm{Cu}$ dominated the fracture behavior of the $\mathrm{FW}$ joint. Fig. $3 \mathrm{c}$ revealed a micro-crack between the $\mathrm{Al}$ and relatively coarse $\mathrm{Cu}$-rich particles in the WM. It is believed that the tensile test properties were negatively affected by the presence of a crack, and the lack of bonding defect at the outer periphery of the weld interface (Fig. 2d), in addition to the effect of presence of $\mathrm{Al}_{2} \mathrm{Cu}$ phase. At the same time, we think that the lack of bonding near the weld flash (see Fig. 2d) had no effect on these properties, because this zone was lathed when preparing the tensile test samples.

The peak temperature reached $436{ }^{\circ} \mathrm{C}$ according to the measurement taken $3 \mathrm{~mm}$ below the abutted surface and at a depth of $2.5 \mathrm{~mm}$ from the outer surface of the $\mathrm{Al}-2 \% \mathrm{Cu}$ bar by the K-type thermocouple. This temperature is below the eutectic temperature and melting point of aluminum, but it should be taken into account where the temperature of $436{ }^{\circ} \mathrm{C}$ was measured as explained above. Thus, the peak temperature may be slightly higher toward the mid-weld interface.

Microstructures of the as-casted Al alloys are given Figs. 5a and d, respectively. The microstructures of the base metals (BMs) formed by the dendritic structure of the $\alpha$-Al solid solution and $\mathrm{Al}_{2} \mathrm{Cu}$ eutectic mixture in the inter-dendritic regions exhibit a net-like feature. In addition, the different copper content led to the different microstructure formation in the BMs [2]. The average grain sizes of $\mathrm{Al}-8 \% \mathrm{Cu} \mathrm{BM}$ and $\mathrm{Al}-$ $2 \% \mathrm{Cu}$ BM were about 82 and $108 \mu \mathrm{m}$, respectively. Some pores were also shown in the base metals under microstructural examination. The FW process under an upset pressure of $32 \mathrm{MPa}$ and upset time of $80 \mathrm{~s}$ led to the occurrence of distinct microstructural zones, i.e. the heat affected zones (HAZ), the thermomechanical affected zones (TMAZ) and the weld metal (WM), in addition to the BM. HAZ at both 

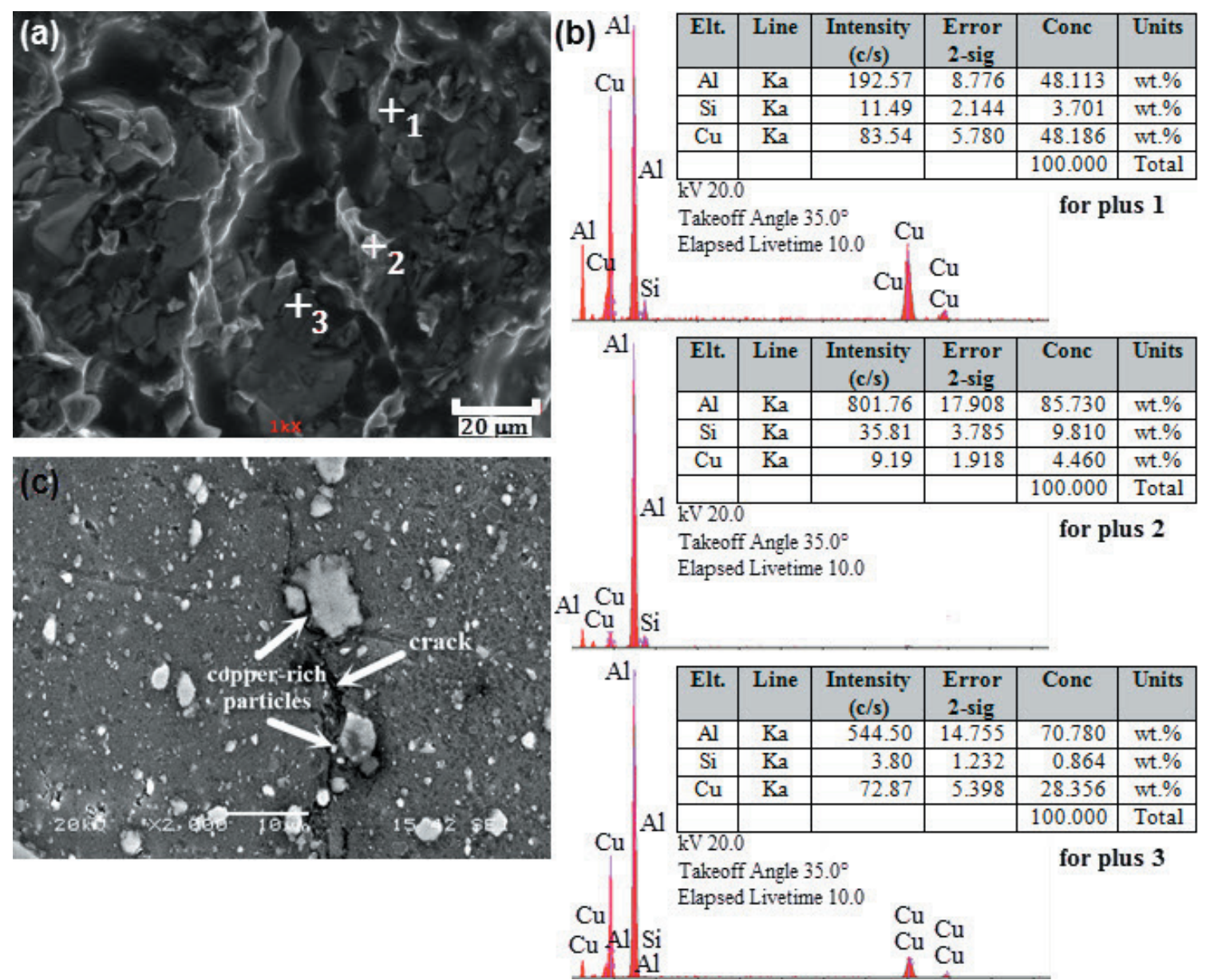

Fig. 3. a) Fracture surface micrograph, b) EDS analysis results of marked by plus signs on the fracture surface, and c) image of a crack along interface between Al and Cu-rich particles in the WM

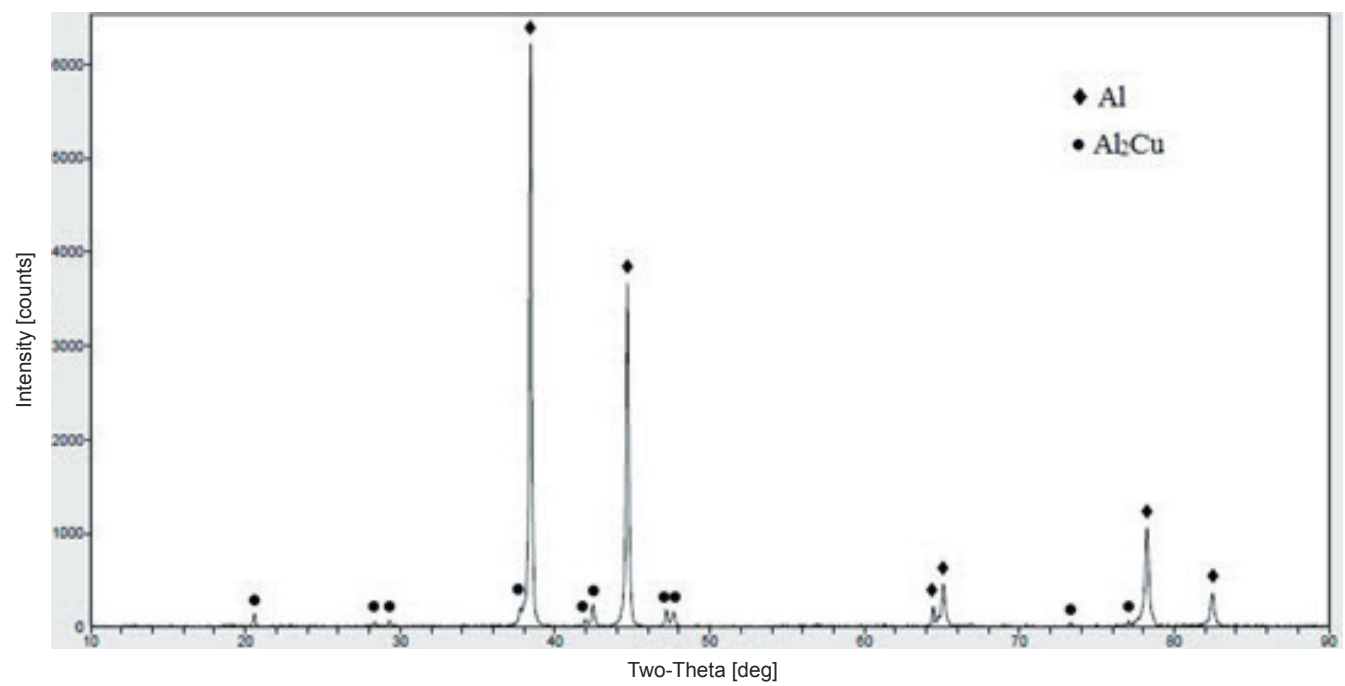

Fig. 4. X-ray diffraction pattern of the fractured surface for S6

side of the weld interface were characterized by a dendrite growth and the average grain size of HAZs for $\mathrm{Al}-8 \% \mathrm{Cu}$ and $\mathrm{Al}-2 \% \mathrm{Cu}$ were about 220 and 174 $\mu \mathrm{m}$, respectively. A reduction in the voids in the inter- 
dendrites was observed in HAZs (Figs. 5b and e) due to elevated temperature and upset pressure and taking into account BM features. Aluminum dendrites were elongated in an upward and downward flow within both TMAZ due to plastic deformation during the FW process (Figs. 5e and f). However, again, the different copper content led to a different TMAZ formation. It is observed that the deformed grains at the RS were distinctly finer than those on the SS. WM (bright region in Fig.2d) showed extremely fine grains and dispersed copper-rich particles (Figs. $5 \mathrm{f}$ and $\mathrm{g}$ ). That is, after the FW process in this zone, a net-like phase and elongated grains transformed to copper-rich particles and fine grains. These features of the weld zone consequently led to a joint efficiency of about 74 to 88 percent with regard to BMs despite the lack of bonding defect at the weld interface.
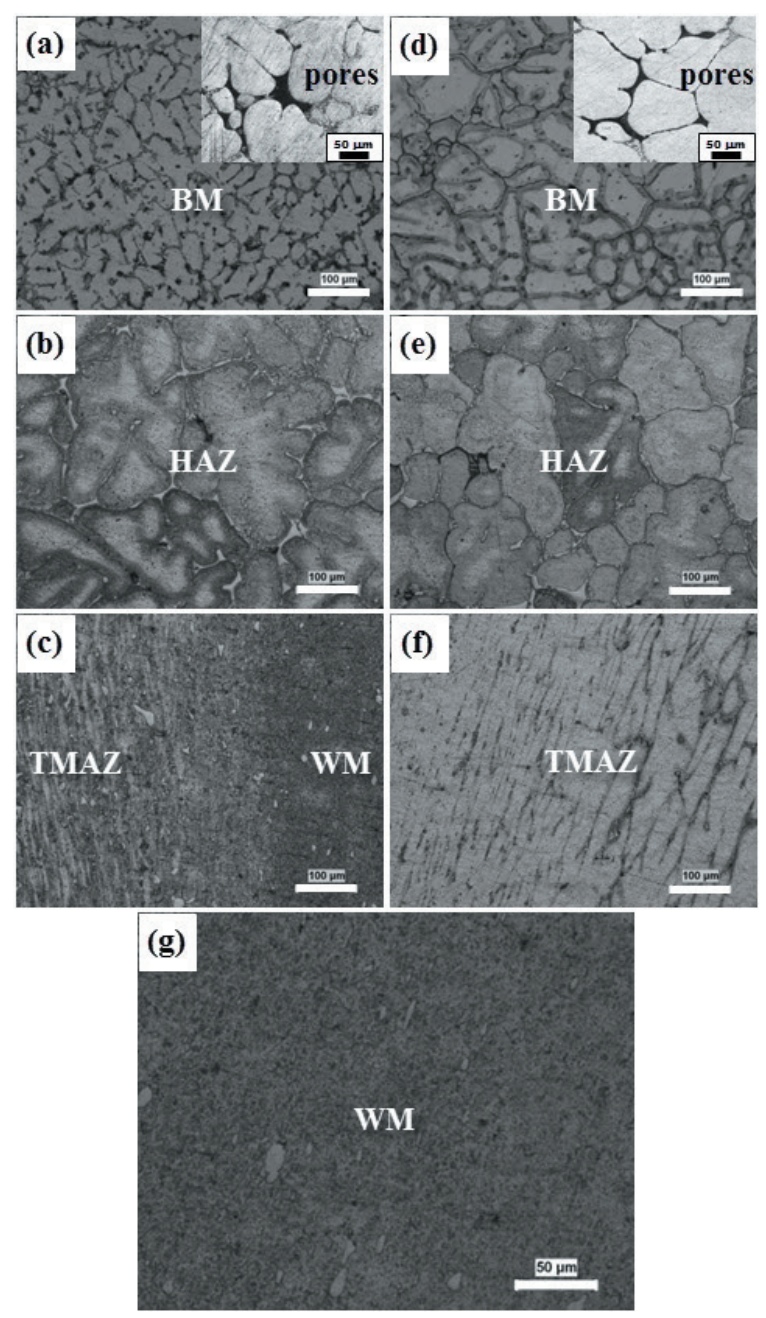

Fig. 5. Micrographs of the weld zone for $\mathrm{S} 6$ a) $\mathrm{BM}$ for $\mathrm{Al}-8 \% \mathrm{Cu}$, b) $H A Z$ at RS, c) TMAZ and WM at RS, d) BM for Al-2\%Cu, e) HAZ at SS, f) TMAZ at SS, and g) central region of WM
The macrohardness of as-casted $\mathrm{Al}-2 \% \mathrm{Cu}$ and $\mathrm{Al}-8 \% \mathrm{Cu}$ is $46 \mathrm{HB}$ and $95 \mathrm{HB}$, respectively. Fig. 6 exhibits macrohardness distribution in the weld zone for S6. It is obvious that the hardnesses increased in the weld zone. As seen in Fig. 6, the hardness trend of RS is also higher than that of SS as a result of the increasing $\mathrm{Cu}$ ratio. The highest macrohardness value, which is $220 \mathrm{HB}$, was measured in WM and this zone has an average hardness of $217 \mathrm{HB}$ across the axis of the friction welded bar. The hardness was also measured near the weld interface and it was observed that the macrohardness changed from 210 to $220 \mathrm{HB}$. Increasing the macrohardness can be mainly attributed to the grain refinement in WM. Vickers microhardness measurements in the weld zone for S6 revealed an unhomogeneous distribution in contrast to the Brinell macrohardness test results, as shown in Fig. 6. Since the hardness values depended on the indenter location, making a clear definition in terms of hardness feature is relatively difficult for the weld zones. Therefore, several measurements were done at different locations apart from the distribution given in Fig. 6. According to the results, the main factor determining the microhardness value was the $\mathrm{Al}_{2} \mathrm{Cu}$ eutectic phase in addition to the grain refinement effect. That is to say, having more $\mathrm{Al}_{2} \mathrm{Cu}$ surrounding the indenter caused an increase in microhardness values (measured up to about $150 \mathrm{HV}$ in WM). Conversely, if the indenter was located at the $\alpha$-Al phase, the microhardness dropped down to about $60 \mathrm{HV}$. Moreover, it is believed that the existence of different $\mathrm{Cu}$ particle size and pores have effects on the hardness tallies with our observations.

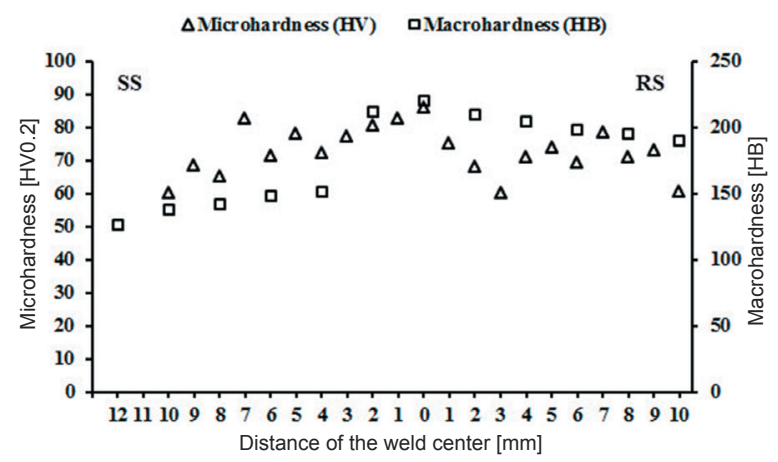

Fig. 6. Hardness profiles across the cross-section for S6

\section{CONCLUSIONS}

Al cast alloy bars with contents of 2 and $8 \% \mathrm{Cu}$ were joined using a vertical milling machine by friction welding. The upset pressure is a more important parameter than the upset time for the joining of dissimilar Al-Cu cast alloys. The UTS of $142 \mathrm{MPa}$ 
can be achieved at an upset pressure of $32 \mathrm{MPa}$ and upset time of $80 \mathrm{~s}$. This value is lower by 12 and $26 \%$ than that of the $\mathrm{Al}-2 \% \mathrm{Cu}$ and $\mathrm{Al}-8 \% \mathrm{Cu}$ base metals, respectively. Typical microstructural zones were observed in the welding zone having the highest UTS. Hardness features in the weld zone were dominated by existence of an $\mathrm{Al}_{2} \mathrm{Cu}$ intermetallic phase and grain refinement.

\section{NOMENCLATURE}

$\begin{array}{ll}\text { FW } & \text { Friction welding } \\ \text { RS } & \text { Rotation side } \\ \text { SS } & \text { Stationary side } \\ \text { BM } & \text { Base metal } \\ \text { HAZ } & \text { Heat affected zone } \\ \text { TMAZ } & \text { Thermo-mechanical affected zone } \\ \text { WM } & \text { Weld metal } \\ \text { UTS } & \text { Ultimate tensile strength } \\ \text { HB } & \text { Hardness Brinell } \\ \text { HV } & \text { Hardness Vickers } \\ \text { SEM } & \text { Scanning electron microscope } \\ \text { EDS } & \text { Energy dispersive X-ray spectroscopy } \\ \text { XRD } & \text { X-ray diffraction }\end{array}$

\section{REFERENCES}

[1] Kaufman, J.G., Rooy, E.L. (2004). Aluminum Alloy Castings Properties Processes and Applications. ASM International, Materials Park.

[2] Zlaticanin, B., Radonjic B., Filipovic, M. (2004). Characterization of Structure and Properties of As-cast AlCuMg Alloys. Materials Transactions, vol. 45, no. 2, p. 440-446, DOI:10.2320/matertrans.45.440.

[3] Kearns, W.H. (Ed.) (1982). Welding Handbook, Metals and Their Weldability. American Welding Society, Miami.

[4] Black, J.T., Kohser, R.A. (2008). DeGarmo's Materials and Processes in Manufacturing. John Wiley \& Sons, Hoboken.

[5] Kurt, A., Uygur, I., Paylasan, U. (2011). Effect of Friction Welding Parameters on Mechanical and Microstructural Properties of Dissimilar AISI 1010 ASTM B22 Joints. Welding Journal, vol. 90, no. 5, p. 102-106.

[6] Liu, W., Wang, F., Yang, X., Li, W. (2013). Upset Prediction in Friction Welding Using Radial Basis Function Neural Network. Advances in Materials Science and Engineering, vol. 2013, p. 1-9, DOI:10.1155/2013/196382.

[7] Murthy, K.N., Raghupathy, V.P., Sethuram D. (eds.) (2011). Two Day Workshop on Friction Welding \& Friction Stir Welding, Indian Welding Society, Kolkata.

[8] Rich, T., Roberts, R. (1971). The Forge Phase of Friction Welding. Welding Journal, p. 137-145.
[9] Yilbas, B.S., Sahin, A.Z., Kahraman N., Al-Garni, A.Z. (1995). Friction Welding of St-Al and Al-Cu Materials. Journal of Materials Processing Technology, vol. 49, no. 3-4, p. 431-443, DOI:10.1016/09240136(94)01349-6.

[10] Rafi, H.K., Ram, G.D.J., Phanikumar, G., Rao, K.P. (2010). Microstructure and Tensile Properties of Friction Welded Aluminum Alloy AA7075-T6. Materials and Design, vol. 31, no. 5, p. 2375-2380, DOI:10.1016/j.matdes.2009.11.065.

[11] Sathiya, P., Aravindan, S., Noorul Haq, A. (2007). Effect of friction welding parameters on mechanical and metallurgical properties of ferritic stainless steel. International Journal of Advanced Manufacturing Technology, vol. 31, no. 11, p. 1076-1082, DOI:10.1007/s00170-005-0285-5.

[12] Fukumoto, S., Tanaka, S., Ono, T., Tsubakino, H., Tomita, T., Aritoshi, M., Okita, K. (2006). Microstructural Development in Friction Welded AZ31 Magnesium Alloy. Materials Transactions, vol. 47, no. 4, p. 1071-1076, DOI:10.2320/matertrans.47.1071.

[13] Sammaiah, P., Suresh, A., Tagore, G.R.N. (2010). Mechanical properties of friction welded 6063 aluminum alloy and austenitic stainless steel. Journal of Materials Science, vol. 45, no. 20, p. 5512-5521, DOI:10.1007/s10853-010-4609-y.

[14] Manideep D., Balachandar, K. (2012). Welding Parameters-Metallurgical Properties Correlation of Friction Welding of Austenitic Stainless Steel and Ferritic Stainless Steel. Journal of Applied Sciences, vol. 12, no. 10, p. 1013-1019, DOI:10.3923/ jas.2012.1013.1019.

[15] Taban, E., Gould, J.E., Lippold, J.C. (2010). Dissimilar Friction Welding of 6061-T6 Aluminum and AISI 1018 Steel: Properties and Microstructural Characterization. Materials and Design, vol. 31, no. 5, p. 2305-2311, DOI:10.1016/j.matdes.2009.12.010.

[16] Sahin, M. (2010). Joining of Aluminium and Copper Materials with Friction Welding. International Journal of Advanced Manufacturing Technology, vol. 49, p. 527-534, DOI:10.1007/s00170-009-2443-7.

[17] Ratković, N., Sedmak, A., Jovanović, M., Lazić, V., Nikolić, R., Krstić, B. (2009). Quality analysis of Al$\mathrm{Cu}$ joint realized by friction welding. Tehnički Vjesnik - Technical Gazette, vol. 16, no. 3, p. 3-7.

[18] Ochi, H., Yamamoto, Y., Yamazaki, T., Sawai, T., Kawai G., Ogawa, K. (2008). Evaluation of tensile strength and fatigue strength of commercial pure Aluminum / tough pitch copper friction-welded joints by deformation heat input. Materials Transactions, vol. 49, no. 12 , p. 2786-2791, DOI:10.2320/matertrans.LMRA2008836.

[19] Ho, C.Y., Ackerman, M.W., Wu, K.Y., Oh, S.G., Havill, T.N. (1978). Thermal Conductivity of Ten Selected Binary Alloy Systems. Journal of Physical and Chemical Reference Data, vol. 7, no. 3, p. 959-1177, DOI:10.1063/1.555583. 